\title{
Chylothorax: a review of 18 cases
}

\author{
A J FAIRFAX, W R MCNABB, S G SPIRO
}

From Brompton Hospital, London

ABSTRACT Eighteen patients who had developed a chylothorax during a 25 year period, 1955-80, $\stackrel{\circ}{\vec{\sim}}$ were reviewed. The chylothoraces occurred as a complication of cardiothoracic surgery in $11_{\perp}^{\times}$ patients, of whom eight were children in the first decade of life. Five cases followed operations for ${ }_{-}^{-}$ coarctation of the aorta and two occurred as a complication of a Blalock shunt for Fallot's tetral- $\overrightarrow{\vec{m}}$ ogy. The chylothorax was evident within 48 hours of the operation in all but two patients. In seveno cases a second operation was performed to prevent further chylous leakage and in two infants theo thoracic duct was ligated. The remainder of the postsurgical chylothoraces responded to either. continuous drainage or repeated aspiration and a low fat diet. There were no late sequelae of $z$ chylothorax following surgery. Spontaneous chylothorax was identified in seven patients and in five of these it was bilateral. Patients with spontaneous chylothorax were all adults and, despite treat-3 ment, had a poor prognosis. Three with malignant disease and two with pulmonary lymph-只 angioleiomyomatosis had died within two years of the appearance of the chylothorax. Two patients $\vec{\bullet}$ with chronic idiopathic chylothoraces survived for more than two years and one of these developedo a secondary fibrothorax.

Chylothorax, the accumulation of thoracic duct lymph or "chyle" in the pleural space, ${ }^{1}$ is a relatively uncommon condition and consequently few clinicians will have experience of more than an occasional case. A chylothorax may occur as a result of trauma to the thoracic duct ${ }^{2}$ or as a complication of oesophageal or cardiothoracic surgery. ${ }^{3-11}$ In malignant disease a chylothorax may occur as a result of blockage or damage to the thoracic lymphatic system. ${ }^{12-16}$ Some spontaneous chylothoraces are idiopathic and in these cases considerable diagnostic difficulties may be encountered in excluding the possibility of an underlying low grade lymphoma. The presence of a chylothorax is indicated by the milky appearance of the aspirated pleural fluid, which separates on standing to form a creamy layer of chylomicrons. The diagnosis may be confirmed by lipoprotein electrophoresis, which also distinguishes a chylothorax from a pseudochylothorax containing a high concentration of cholesterol or lecithin-globulin complexes, or both. ${ }^{117}$

In this review we report a group of patients, identified by means of the Brompton Hospital diag-

Address for reprint requests: Dr A J Fairfax, Department of Thoracic Medicine, Staffordshire General Infirmary, Stafford ST16 2PA.

Accepted 8 April 1986 nostic index, who developed a chylothorax of anyo aetiology during the 25 year period 1955-80. The management and outcome of these cases are briefly $\overrightarrow{\vec{B}}$ described.

\section{Methods}

\section{PATIENTS}

Eighteen patients ( 11 male) were identified who had $a \times$ definite diagnosis of chylothorax. In most cases theo diagnosis had been made clinically by demonstration of a milky effusion and had been confirmed by lipido analysis of the aspirated fluid. ${ }^{17}$ The age at onset of 2 the chylothorax varied from 1 week to 78 years. Weo give three illustrative case histories.

Case 7

A 6 year old child had a resection of a coarctation of the aorta and division of a patent ductus arteriosus $\widetilde{O}$ At operation lymphoid tissue was noted to be over $-\mathrm{W}$ lying the site of coarctation. After the resection theo mediastinal pleura was reconstituted. A chest radio graph taken seven days after operation showed a left్ sided effusion; this increased in size and when on the? 13th postoperative day it was drained it produced 10 litre of chyle. Drainage continued and 17 days later $a \overline{\bar{O}}$ second thoracotomy was performed. The leak of chyle was from lymphatic channels associated with 
large lymph node lying between the left subclavian artery and the aorta.

This defect was oversewn. An attempt was made to find and ligate the thoracic duct at the diaphragmatic hiatus but this was unsuccessful. After the operation there was no recurrence of the chylothorax.

\section{Case 14}

A 55 year old woman, known previously to have had a normal chest radiograph, spontaneously developed bilateral pleural effusions, found on aspiration to be chylous. There was no history of trauma and a diagnosis of lymphoma was suspected. A lymphogram outlined the lymphatics up to the lower para-aortic group, which were normal, but no filling occurred above that level. The thoracic duct failed to opacify. The only abnormality seen was a fine network of lymphatics to the right of the 12th thoracic and first lumbar vertebrae, possibly communicating with the right pleural cavity. The biochemical composition of the chyle from the two hemithoraces was similar, with a triglyceride concentration of $15.9-17.4 \mathrm{mmol} / \mathrm{l}$ $(1407-1540 \mathrm{mg} / 100 \mathrm{ml})$ and cholesterol concentration of $2.6-2.8 \mathrm{mmol} / 1 \quad(100 \cdot 4-108 \cdot 1 \mathrm{mg} / 100 \mathrm{ml})$. The immunoglobulin concentrations in the chyle were: IgG $793 \mathrm{IU} / \mathrm{ml}, \operatorname{IgA} 58 \mathrm{IU} / \mathrm{ml}$, IgM $179 \mathrm{IU} / 1$, with corresponding serum concentrations of $\mathrm{IgG} 177 \mathrm{IU} / \mathrm{l}$, IgA $182 \mathrm{IU} / 1$, and IgM $290 \mathrm{IU} / 1$. The pleural fluid protein content was $29 \mathrm{~g} / \mathrm{l}$. An extensive series of investigations were performed, including a radiographic skeletal survey; isotope liver, spleen, and bone scans; and biopsies of the bone marrow and liver, all of which failed to show evidence of a lymphoma. Computed tomography of the abdomen suggested the presence of enlarged lymph nodes in the para-aortic region. Consequently, three months after presentation, a laparotomy and liver biopsy were performed but no evidence of lymphoma was found.

The pleural effusions persisted and required repeated aspirations. Four years after the onset these became infected with Clostridium welchii. The patient was treated with parenteral antibiotics and the effusions were aspirated to dryness. After a severe illness she recovered. Both pleural spaces became loculated, making further aspiration difficult. Five years after presentation she remained well but was left with a moderately severe, predominantly restrictive ventilatory defect $\left(\mathrm{FEV}_{1}\right.$ and FVC both $46 \%$ of the predicted normal values).

\section{Case 15}

A 57 year old man presented with a four week history of shortness of breath on exertion. Initially there was no weight loss or symptoms to indicate a malignant disease. He was found to have a large right pleural effusion and hepatomegaly. Pleural aspiration pro- duced 31 of cream coloured fluid containing lymphocytes and mesothelial cells. A pleural biopsy showed chronic inflammation only. Further aspirations yielded pleural fluid containing $46 \mathrm{~g} / 1$ protein, with a triglyceride concentration of $5.3-11.7 \mathrm{mmol} / 1$ $(469-1035 \mathrm{mg} / 100 \mathrm{ml})$ and a cholesterol concentration of $1 \cdot 8-3 \cdot 1 \mathrm{mmol} / 1 \quad(69 \cdot 5-119 \cdot 7 \mathrm{mg} / 100 \mathrm{ml})$. Lipoprotein electrophoresis of the pleural fluid showed chylomicrons and pre- $\beta$ lipoproteins. After oral administration of $1 \mathrm{~g}$ of Sudan III the pleural effusion became stained pink. One month later a left chylothorax appeared. A lymphogram showed a congenital anomaly of the thoracic duct with persistence of the two embryological lymph ducts below the level of the arch of the aorta. There were slightly abnormal lymph nodes present in both para-aortic regions and on both sides of the pelvis. The cause of the bilateral chylothoraces was thought to be a congenital abnormality of the lymphatic system. Computed tomography of the lower thorax and upper abdomen, however, showed enlargement of the para-aortic nodes and a mass behind the right crus of the diaphragm extending upwards into the posterior mediastinum. The appearances suggested the presence of a lymphoma.

Over a period of 70 days a total of 56.21 of chyle was either aspirated or drained from the chest. The total protein removed by aspiration of chyle amounted to about $37 \mathrm{~g}$ a day. The plasma protein concentration fell from 61 to $48 \mathrm{~g} / 1$ and the plasma albumin from 40 to $24 \mathrm{~g} / \mathrm{l}$. A right thoracotomy was performed, which showed that the pleura was generally thickened. The mediastinal lymph nodes were infiltrated by a lymphocytic, well differentiated nodular lymphoma. A right pleurodesis was effected to prevent further accumulation of pleural fluid. The patient subsequently developed chylous ascites, however. He was treated with radiotherapy and chemotherapy but died 10 months after his presenting right chylothorax.

\section{Results}

In 11 of the 18 patients a chylothorax followed cardiothoracic surgery. The most common single cause was the operation for resection of a coarctation of the aorta (five cases of chylothorax from 554 operations). Eight of the 11 cases of surgical chylothorax occurred on the left side. Two right sided effusions were the result of right Blalock shunt operations for Fallot's tetralogy. In nine of the 11 patients the chylothorax was evident within 48 hours of operation. In two cases, however, there was a latent period, of seven and 10 days respectively, before sufficient fluid had accumulated for it to be detected. The duration of continuing accumulation of chyle in the pleural space 
Table 1 Details and management of 11 patients with a chylothorax following surgery

\begin{tabular}{|c|c|c|c|c|c|c|c|c|c|}
\hline \multirow[b]{2}{*}{$\begin{array}{l}\text { Patient } \\
\text { No }\end{array}$} & \multirow[b]{2}{*}{ Age } & \multirow[b]{2}{*}{$\operatorname{Sex}$} & \multirow[b]{2}{*}{ Operation } & \multirow[b]{2}{*}{$\begin{array}{l}\text { Latent } \\
\text { period }\end{array}$} & \multirow[b]{2}{*}{ Side } & \multirow[b]{2}{*}{ Duration } & \multicolumn{2}{|l|}{ Treatment } & \multirow[b]{2}{*}{ Complications } \\
\hline & & & & & & & $\begin{array}{l}\text { Drainage/ } \\
\text { aspiration }\end{array}$ & Operative & \\
\hline 1 & $4 d$ & $\mathrm{~F}$ & R Blalock (Fallot's) & $2 \mathrm{~d}$ & $\mathbf{R}$ & $3 \mathrm{~d}$ & CD & - & - \\
\hline 2 & $1 y$ & $\mathbf{M}$ & R Blalock (Fallot's) & $1 \mathrm{~d}$ & $\mathbf{R}$ & $15 \mathrm{~d}$ & CD & Defect oversewn & - \\
\hline 3 & $1 y$ & $\mathbf{F}$ & $\begin{array}{l}\text { Resection of } \\
\text { coarctation (Turner's }\end{array}$ & & & & & & \\
\hline & & & syndrome) & $<24 \mathrm{~h}$ & $\mathbf{L}$ & $9 \mathrm{~d}$ & $\mathrm{CD}$ & TD ligation & - \\
\hline 4 & $1 \mathrm{y}$ & $\mathrm{F}$ & Ligation of PDA & $1 d$ & L & $50 \mathrm{~d}$ & RA & & - \\
\hline 5 & $2 y$ & M & $\begin{array}{l}\text { Mustard procedure } \\
\text { (transposition) }\end{array}$ & $\begin{array}{l}10 \mathrm{~d} \\
29 \mathrm{~d}\end{array}$ & $\begin{array}{l}\mathbf{R} \\
\mathbf{L}\end{array}$ & $\begin{aligned} 21 \mathrm{~d} \\
2 \mathrm{~d}\end{aligned}$ & $\mathrm{CD}$ & $\begin{array}{l}\text { Revision mustard } \\
\text { Talc pleurodesis }\end{array}$ & $\begin{array}{l}\text { Died after } \\
15 \text { months }\end{array}$ \\
\hline 6 & $2 y$ & $\mathrm{~F}$ & $\begin{array}{l}\text { Resection of } \\
\text { coarctation, PDA }\end{array}$ & & & & & & \\
\hline & & & VSD & $<24 \mathrm{~h}$ & $\mathbf{L}$ & $4 d$ & $\mathrm{CD}$ & TD ligation & - \\
\hline 7 & $6 y$ & $\mathbf{F}$ & $\begin{array}{l}\text { Resection of } \\
\text { coarctation, PDA }\end{array}$ & $7 \mathrm{~d}$ & $\mathbf{L}$ & $17 \mathrm{~d}$ & $\mathrm{CD}$ & Defect oversewn & - \\
\hline 8 & $8 y$ & $\mathbf{M}$ & $\begin{array}{l}\text { Angioplastic repair } \\
\text { of coarctation }\end{array}$ & $<24 \mathrm{~h}$ & L & $12 \mathrm{~d}$ & RA & 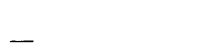 & - \\
\hline 9 & $49 y$ & $\mathbf{M}$ & $\begin{array}{l}\text { Resection of } \\
\text { coarctation }\end{array}$ & $2 d$ & $\mathbf{L}^{*}$ & $56 \mathrm{~d}$ & RA & Defect oversewn & - \\
\hline 10 & $48 y$ & $\mathbf{M}$ & $\begin{array}{l}\mathrm{L} \text { thoracoplasty } \\
\text { for tuberculosis }\end{array}$ & $<24 \mathrm{~h}$ & L & $21 \mathrm{~d}$ & RA & Defect oversewn & - \\
\hline 11 & $66 y$ & $\mathbf{M}$ & $\begin{array}{l}\text { Excision of leiomyoma } \\
\text { of oesophagus }\end{array}$ & $1 \mathrm{~d}$ & $\mathbf{R}$ & $14 \mathrm{~d}$ & $\mathrm{CD}$ & Defect oversewn & - \\
\hline
\end{tabular}

${ }^{*}$ Chylomediastinum.

$\mathrm{CD}$-continuous intercostal drainage; TD—-thoracic duct; VSD—ventricular septal defect; RA—repeated aspiration; PDA-patent ductus arteriosus.

varied from two to 56 days (table 1 ).

Common treatment in the surgical group included continuous tube drainage (seven cases) or repeated aspirations (four cases) and the institution of a low fat, high protein diet with medium chain triglyceride supplementation. The effect of reducing the dietary fat intake in a baby with a chylothorax following a Blalock shunt for Fallot's tetralogy (case 2, table 1) is shown in the figure. The triglyceride content of the effusion decreased considerably after the restriction of fat intake and the substitution of medium chain triglycerides in the diet. In seven cases a second operation was performed either to oversew the source of the leak of chylous fluid into the pleural space or (in two cases) to ligate the thoracic duct proximal to the leak. The duration of leakage of chyle before a second operation was undertaken varied from four to 56 days. In one patient, a 17 month old baby undergoing ligation of a patent ductus arteriosus (case 4, table 1), repeated aspiration of the chylothorax was continued for 50 days without complication and no further accumulation of fluid occurred after this time. Most of the postoperative cases of chylothorax followed operations on the great vessels. Three chylothoraces in adults occurred after surgery; one followed surgical treatment of coarctation of the aorta, one followed a left thoracoplasty for tuberculosis, and the other occurred after excision of a leiomyoma of the oesophagus in a 66 year old man. The remaining adult cases were non-surgical. All of the chylothoraces seen in childhood followed surgery.
A summary of the patients with a spontaneous chylothorax is shown in table 2 . In three patients, aged 57-72 years, a unilateral or bilateral chylothorax was $\overline{0}$ a presenting feature of a malignant lymphoma. These $\stackrel{\circ}{\circ}$ patients were treated by repeated aspiration and in $\triangle$

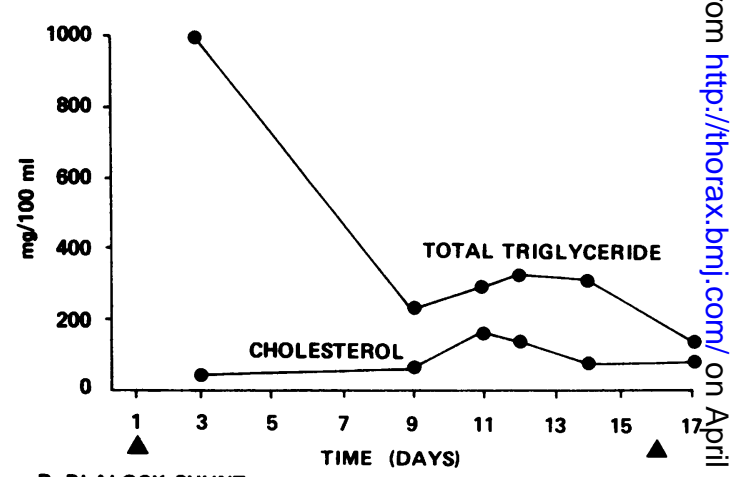

R BLALOCK SHUNT

REPAIR OF LEAK $N$

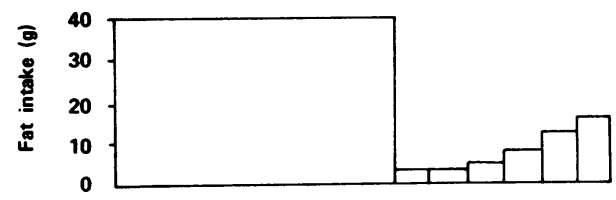

Effect of dietary fat restriction on the composition of chyle in an infant aged 18 months. The chylothorax followed a Blalock shunt for Fallot's tetralogy. 
Table 2 Characteristics and outcome of seven patients with a spontaneous chylothorax

\begin{tabular}{|c|c|c|c|c|c|c|c|}
\hline $\begin{array}{l}\text { Patient } \\
\text { No }\end{array}$ & $\begin{array}{l}\text { Age } \\
\text { at onset } \\
\text { (y) }\end{array}$ & Sex & Aetiology & Side & $\begin{array}{l}\text { Duration of } \\
\text { chylothorax }\end{array}$ & Treatment & Outcome \\
\hline 12 & 34 & $F$ & $\begin{array}{l}\text { Pulmonary lymph- } \\
\text { angioleiomyomatosis }\end{array}$ & $\mathbf{R}$ & $2 \mathrm{~m}$ & $\begin{array}{l}\text { Thoracotomy, } \\
\text { R pleurodesis }\end{array}$ & $\begin{array}{l}\text { Died after } \\
13 \text { months }\end{array}$ \\
\hline 13 & 51 & $\mathbf{M}$ & $\begin{array}{l}\text { Lymphangioleio- } \\
\text { myomatosis }\end{array}$ & Both & $22 \mathrm{~m}$ & $\begin{array}{l}\mathrm{RA} \text { and } \mathrm{CD}, \mathrm{L} \text { decortication, } \\
\text { pleurodesis, radiotherapy }\end{array}$ & $\begin{array}{l}\text { Died after } \\
22 \text { months }\end{array}$ \\
\hline $\begin{array}{l}14 \\
15\end{array}$ & $\begin{array}{l}55 \\
57\end{array}$ & $\begin{array}{l}\mathbf{F} \\
\mathbf{M}\end{array}$ & $\begin{array}{l}\text { Idiopathic } \\
\text { Malignant lymphoma }\end{array}$ & $\begin{array}{l}\text { Both } \\
\text { Both, with } \\
\text { ascites }\end{array}$ & $\begin{array}{r}8 \mathrm{y} \\
10 \mathrm{~m}\end{array}$ & $\begin{array}{l}\text { RA } \\
\text { RA, R decortication, } \\
\text { radiotherapy, } \\
\text { chemotherapy }\end{array}$ & $\begin{array}{l}\text { Alive and well } \\
\text { Died after } \\
10 \text { months }\end{array}$ \\
\hline 16 & 60 & $\mathbf{M}$ & $\begin{array}{l}\text { Malignant lymphoma } \\
\text { with }\end{array}$ & & & RA chemotherany & Died after \\
\hline 17 & 72 & $\mathbf{M}$ & $\begin{array}{l}\text { macrogiooumnaemia } \\
\text { Malignant lymphoma }\end{array}$ & Both & $\begin{array}{l}10 \mathrm{~m} \\
7 \mathrm{w}\end{array}$ & $\begin{array}{l}\text { RA, cnemotnerapy } \\
\text { RA }\end{array}$ & $\begin{array}{l}\text { Died after } \\
7 \text { weeks }\end{array}$ \\
\hline 18 & 78 & $\mathbf{M}$ & Idiopathic & Both & $31 \mathrm{~m}$ & RA & $\begin{array}{l}\text { Alive: L } \\
\text { fibrothorax }\end{array}$ \\
\hline
\end{tabular}

RA--repeated aspiration; CD - continuous intercostal drainage.

two cases with chemotherapy. Despite active treatment, all three died within 18 months of the appearance of a chylothorax. In two patients the chylothorax was attributed to pulmonary lymphangioleiomyomatosis. Surgical attempts at pleurodesis were made in both cases and both patients died within two years of initiation of treatment. In this series there were two patients with idiopathic chylothoraces. No cause was found despite very extensive investigations to exclude the possibility of malignant disease and lymphoma, as illustrated by case 14 above. Both had bilateral effusions and were treated with recurrent aspirations. In one of these patients, a man aged 78 at the onset of the chylothorax, a left fibrothorax developed subsequently.

\section{Discussion}

The causes of chylothorax may be broadly divided into four major categories: malignant disease, trauma, idiopathic, and miscellaneous. ${ }^{1}$ The traumatic causes include injuries from penetrating wounds or from hyperextension of the spine $^{2}$ and surgery to the thorax or to the left side of the neck. ${ }^{3-11}$ Chylothorax has been reported after surgery for congenital heart disease, ${ }^{6}$ coronary artery surgery, ${ }^{10}$ oesophagoscopy and oesophageal resection, ${ }^{4}$ Bochdalek herniorrhaphy, ${ }^{5}$ and pneumonectomy. ${ }^{11}$ Spontaneous chylothorax may occur during the course of a malignant disease such as lymphoma or bronchogenic carcinoma. ${ }^{1314}$ There are some rare causes of chylothorax, including congenital chylothorax, ${ }^{18}$ aortic aneurysms, subclavian vein thrombosis, filariasis, and thoracic duct tumours. ${ }^{1}$ About $75 \%$ of patients with pulmonary lymphangioleiomyomatosis present with a chylothorax. ${ }^{19}$
In this series operations for resection of a coarctation of the aorta were the most common single cause of a subsequent chylothorax. Most surgical cases followed paediatric cardiac surgery, reflecting the referral pattern to the Brompton Hospital. The delayed accumulation of a chylothorax after surgery is well described ${ }^{16}$ and this was a feature in two of the 11 patients in this series. In one patient (case 9) a mediastinal collection of chyle ("chyloma") was visible radiographically before rupturing into the pleural space as a chylothorax.

The diagnosis of a chylothorax may be confirmed by lipid analysis of the fluid. Usually the total lipid varies from 4 to $40 \mathrm{~g} / 1$ and characteristically has a high triglyceride (varying with diet) and a low cholesterol concentration. Lipoprotein electrophoresis shows a chylomicron band. ${ }^{17} \mathrm{~A}$ chylothorax typically contains lymphocytes $\left(0.4-6.0 \times 10^{9} / 1\right)$ and erythrocytes $\left(0.05-0.6 \times 10^{9} / 1\right)$ and has a high protein content $(>30 \mathrm{~g} / \mathrm{l})$. It is rarely necessary to give lipophilic dyes by mouth ${ }^{1520}$ or radiolabelled triglyceride ${ }^{21}$ to confirm the presence of a chylothorax provided that the fluid aspirated is sent for biochemical analysis. ${ }^{17}$

Diagnostic difficulties may occur in the search for the cause of a spontaneous chylothorax. Despite extensive investigations, some cases of chylothorax remain unexplained and are termed idiopathic, and these may be difficult to separate from cases resulting from mild trauma such as stretching or from chylothorax secondary to an occult malignancy. Lymphangiography may be useful in localisation of the leak of chylous fluid. ${ }^{22}$ In case 15 lymphography showed a congenital abnormality of the lymphatic system but failed to identify the presence of a lymphoma. This was, however, seen on abdominal and thoracic computed tomography scans. Upper abdominal ultrasonography is another potentially useful non-invasive 
technique. In cases where computed tomography shows enlarged abdominal or mediastinal lymph nodes in the absence of palpably accessible nodes (as in case 14) there may be no alternative to an exploratory laparotomy or thoractomy.

The management of chylous effusions comprises the maintenance of nutrition, the reduction of flow in thoracic duct lymph, and the maintenance of full expansion of the affected lung. Treatment aimed at minimising chyle formation includes bed rest and either total parenteral nutrition or a high protein diet with dietary fat replaced by medium chain triglycerides, or both. ${ }^{23-26}$ Treatment with digoxin and diuretics has been advocated where necessary to lower the central venous pressure. The chylothorax is usually aspirated either by repeated thoracocentesis for up to four weeks or by the insertion of an intercostal drain. Operative treatment includes oversewing the source of leakage of chyle and thoracic duct ligation, which was performed in two of the surgical cases. In spontaneous chylothorax there are risks in prolonged conservative treatment since there may be considerable losses of fluid (up to 2.5 litres daily), protein, fat, and lymphocytes, resulting in thirst, weakness, hypoproteinaemia, and immunological abnormalities. ${ }^{27}$ Secondary infection is another danger. In addition, there are possible late complications, such as loculation of the effusion and the development of fibrothorax.

In idiopathic chylothorax and also in chylothorax secondary to malignant disease, tetracycline, talc pleurodesis or even pleurectomy ${ }^{28-32}$ should be considered at a fairly early stage since, as in case 15 , repeated aspiration may not solve the problem. To facilitate chemical pleurodesis the measures outlined above to minimise the formation of chyle should be taken until the pleurae are adherent.

In our series the development of a spontaneous chylothorax in the seven adults described was an ominous finding, and five of these had died within two years of the occurrence. The cause of death reflected the underlying pathological process rather than the presence of the chylothorax. Two patients, however, remainded alive and well after several years with idiopathic chylothorax.

We would like to thank all the consultant physicians, surgeons, and cardiologists at the Brompton Hospital for permission to include cases under their care. We also wish to thank Miss $\mathrm{L}$ Waldron for typing the manuscript.

\section{References}

1 Sassoon CS, Light RW. Chylothorax and pseudochylothorax. Clin Chest Med 1985;6:163-71.
2 Goorwitch J. Traumatic chylothorax and thoracic duct ligation. $J$ Thorac Surg 1955;29:467-79.

3 Cevese PG, Vecchione R, D'Amico DF, et al. Post-드 operative chylothorax. Six cases in 2,500 operations, with a survey of the world literature. $J$ Thorac Cardio $\frac{\text { क }}{\vec{D}}$ vasc Surg 1975;69:966-70.

4 Lam KH, Lim STK, Wong J, Ong GB. Chylothoraxu following resection of the oesophagus. Br J Surges 1979;66:105-9.

5 Wiener ES, Owens L, Salzberg AM. Chylothorax afterBochdalek herniorrhaphy in a neonate. $J$ Thorac $\vec{\omega}$ Cardiovasc Surg 1973;65:200-6.

6 Higgins CB, Mulder DG. Chylothorax after surgery for congenital heart disease. J Thorac Cardiovasc Surg 1971;61:411-8.

7 Tandon RK. Chylothorax after repair of ventricular sep- $-\overrightarrow{-}$ tal defect. J Thorac Cardiovasc Surg 1968;56:378-80. $\infty$

$8 \mathrm{Kaul}$ TK, Bain WH, Turner MA, Taylor KM. Chylo-o thorax: report of a case complicating ductus ligations through a median sternotomy, and review. Thorax1976;31:610-6.

9 Joyce LD, Lindsay WG, Nicoloff DM. Chylothorax after median sternotomy for intrapericardial cardiac? surgery. J Thorac Cardiovasc Surg 1976;71:476-80. 응

10 Weber DO, Mastro PD, Yarnoz MD. Chylothorax after myocardial revascularization with internal mammary ${ }_{\vec{O}}$ graft. Ann Thorac Surg 1981;32:499-502.

11 Mulders AV, Lacquet LM, Mieghem WV, Deneffe G: Chylothorax complicating pneumonectomy. Thorax 1984;39:954-5.

12 Schmidt A. Chylothorax. Review of 5 years' cases in the literature and report of a case. Acta Chir Scand 1959;118:5-12.

13 Bower GC. Chylothorax. Observations in 20 cases. Dis Chest 1964;46:464-8.

14 Roy PH, Carr DT, Payne WS. The problem of chylo thorax. Mayo Clinic Proc 1967;42:457-67.

15 Bessone LN, Ferguson TB, Burford TH. Chylothorax Ann Thorac Surg 1971;12:527-50.

16 Macfarlane JR, Holman CW. Chylothorax. Am Revo Respir Dis 1972;105:287-91.

17 Seriff NS, Cohen ML, Samuel P, Schulster PL. Chylo thorax: diagnosis by lipoprotein electrophoresis of serum and pleural fluid. Thorax 1977;32:98-100.

18 Jeske W. Chylothorax in infancy. Thorax 1968;23:214-5.

19 Carrington CB, Cugell DW, Gaensler EA, et al. Lymph-? angioleiomyomatosis: physiologic-pathologic radio은 logic correlations. Am Rev Respir Dis 1977;116 977-95.

20 Klempser RG, Berry JF. The diagnosis and surgica management of chylothorax with the aid of lipophilies dyes. Dis Chest 1954;25:409-26.

21 Woolfenden JM, Struse TB. Diagnosis of chylothoran with ${ }^{131} \mathrm{I}$-triolein: case report. $J \mathrm{Nucl} \mathrm{Med}^{\$ \omega}$ 1977;18:128-9.

22 Heilman RD, Collins VP. Identification of laceration of the thoracic duct by lymphangiography. Radiolog $x \bar{D}$ 1963;81:470-2.

23 Hashim SA, Roholt HB, Babayan VK, Itallie TBV:Treatment of chyluria and chylothorax with medium chain triglyceride. $N$ Engl J Med 1964;270:756-61.

24 Gershanik JJ, Jonsson HT, Riopel DA, Packer RM $\frac{\rho}{\mathscr{D}}$ 
Dietary management of neonatal chylothorax. Pediatrics 1974;53:400-3.

25 Craenen JM, Williams TE, Kilman JW. Simplified management of chylothorax in neonates and infants. $A n n$ Thorac Surg 1977;24:275-7.

26 Maloney JV, Spencer FC. The nonoperative treatment of traumatic chylothorax. Surgery (St Louis) 1956;40:121-8.

27 Machleder HI, Paulus H. Clinical and immunological alterations observed in patients undergoing long-term thoracic duct drainage. Surgery 1978;84:157-65.

28 Ross JK. A review of the surgery of the thoracic duct.

\section{Book notice}

\begin{abstract}
Mechanical Ventilation. Physiological and Clinical Applications. (Faculty Lecture Series in Respiratory Care.) Susan P Pilbeam. (Pp 375; figs; $£ 18$ softback.) Denver, Colorado: Multi-Media Publishing Inc, 1986. ISBN 0940122189.
\end{abstract}

This book is written by a respiratory therapist for the guidance of trainees in respiratory therapy. There are no equivalent specialists in the United Kingdom, although a good deal of the work covered by them is performed by physiotherapists. The book concentrates on the technical and physiological aspects of mechanical ventilation and does not attempt to explore in depth its more medical aims and consequences. It is very well produced, with clear and simple diagrams. Inevitably many of the statements made are rather rigid and simplistic; for example, reference to the Radford nomogram and to data derived from this is relied on very heavily in the recommendations about ventilatory settings. The book is very easy to read, has useful references at the end of each chapter, and could be read with benefit by anyone who is starting off in a branch of medicine in which contact with mechanical ventilation is to be anticipated.-JCS
Thorax 1961;16:12-21.

29 Bruneau R, Rubin P. The management of pleural effusions and chylothorax in lymphoma. Radiology 1965;85:1085-92.

30 Gingell JC. Treatment of chylothorax by producing pleurodesis using iodized talc. Thorax 1965;20:261-9.

31 Selle JG, Snyder WH, Schreiber JT. Chylothorax: indications for surgery. Ann Surg 1973;177:245-9.

32 Adler RH, Levinsky L. Persistent chylothorax. Treatment by talc pleurodesis $J$ Thorac Cardiovasc Surg 1978;76:859-64.

\section{Notices}

\section{Cystic fibrosis}

A special all day meeting will be held in Manchester, by the paediatrics section of the Royal Society of Medicine, on "The Current Clinical Management of Cystic Fibrosis" on 18 February 1987. Further details are available from Dr TJ David, Booth Hall Children's Hospital, Manchester M9 2AA.

\section{Lung pathology course}

A course on lung pathology will be held at the Brompton Hospital, London, on 16-18 March 1987. Further details may be obtained from the Postgraduate Course Secretary, Cardiothoracic Institute, London SW3 6HP.

\section{Interaction between heart and lung}

An international congress entitled "Interaction Between Heart and Lung," sponsored by the European Society of Cardiology and the European Society for Clinical Respiratory Physiology, will be held in Munich from 9 to 11 April 1987. Further information may be obtained from Dr med HP Emslander, I Med Klinik TUM, Klinikum rechts der Isar, Ismaninger Str 22, D 8000 Munchen 80, Federal Republic of Germany.

17th Annual Fleischner Society Symposium on Chest Disease

The 17th Annual Fleischner Society Symposium on Chest Disease will be held from 21 to 23 May 1987 at the St Francis Hotel, San Francisco, California. Further information may be obtained from Nomi Feldman, 3770 Tansy, San Diego, California 92121, USA. 